Ouitzkı, A. L. (1952). J. gen. Microbiol. 6, 166-174

\title{
The Determination of the Most Probable Numbers of Streptomycin-fast Cells in Brucella Cultures and their Variability in Growing and Ageing Cultures
}

\author{
By A. L. OLITZKI \\ Department of Bacteriology, Hebrew University-Hadassah Medical School, \\ Jerusalem, Israel
}

SUMMARY: The method of most probable numbers (MPN) was employed in order to determine the number of resistant brucella cells at concentrations of streptomycin of 1,10 and $100 \mu \mathrm{g} . / \mathrm{ml}$. The examination showed agreement with the centrifugation method (plating of the sediment of at least $100 \mathrm{ml}$. of culture together with the required concentration of streptomycin) in a range up to 1000 resistant cells/100 ml. The method showed that there exist differences in the numbers of resistant cells in different strains, and that in cultures originating from the same colony variations occur. The general trend is a rlative increase of the resistant cells with the age of the culture.

Methods for determining the number of streptomycin-resistant cells in bacterial cultures have been described by many authors. Klein \& Kimmelman (1946) employed broth cultures of Shigella dysenteriae. Tenfold dilutions up to $10^{-6}$ were assayed in varying concentrations of streptomycin in melted agar, the test requiring at least 42 plates. In another experiment they distributed $40 \mathrm{ml}$. of broth culture into 400 broth tubes containing 1000 units streptomycin $/ \mathrm{ml}$. After $48 \mathrm{hr}$, growth appeared in 5 out of 400 tubes. Yegian \& Vanderlinde (1948) incubated different sizes of inocula of Mycobacterium ranae on glycerol agar with varying quantities of streptomycin; one test required at least 120 plates. English \& McCoy (1951) incubated 100 tubes containing $0.3 \mathrm{ml}$. broth culture of Micrococcus pyogenes and 200 units of streptomycin. One tube out of 100 showed visible growth after $24 \mathrm{hr}$. They estimated the number of bacteria incubated in 100 tubes at $67 \times 10^{8}$ and concluded, therefore, that one resistant cell was present in this total bacterial population. All these methods require large quantities of tubes, agar and plates, and are time and material consuming. We tried, therefore, to simplify this technique by the determination of the most probable number (MPN) of streptomycin resistant micro-organisms in a culture. This method was proposed by McCrady (1915) for the numerical interpretation of fermentation tube results. For our purposes, the determination of small numbers of streptomycin resistant cells in a large bacterial population, we used the tables published by Hoskins (1934), reprinted in Standard Methods for the Examination of Water and Sewage (1936). We expected that with this relatively simple technique it would be possible to detect the presence of streptomycin resistant organisms in brucella cultures at different stages of their incubation. 


\section{METHODS AND RESULTS}

Preliminary experiments were made to determine the action of streptomycin on the whole bacterial population, and the time of the first visible growth of resistant bacteria at different levels of streptomycin. The methods employed were as follows:

Media. The liquid media contained, per litre, $30 \cdot 0 \mathrm{~g}$. dehydrated trypticase soy broth (Baltimore Biological Laboratories), $30.0 \mathrm{ml}$. glycerol and $1.0 \mathrm{ml}$. of a solution of aneurin containing $0 \cdot 1 \mathrm{mg} . / \mathrm{ml}$.

Strains. Two strains of Brucella melitensis, M5 and M7, two strains of Br. suis, S39 and S6, and two strains of Br. abortus, A 19 and A 2308, were used. After several subcultures on the above medium $24 \mathrm{hr}$. cultures were used for the experiments described below.

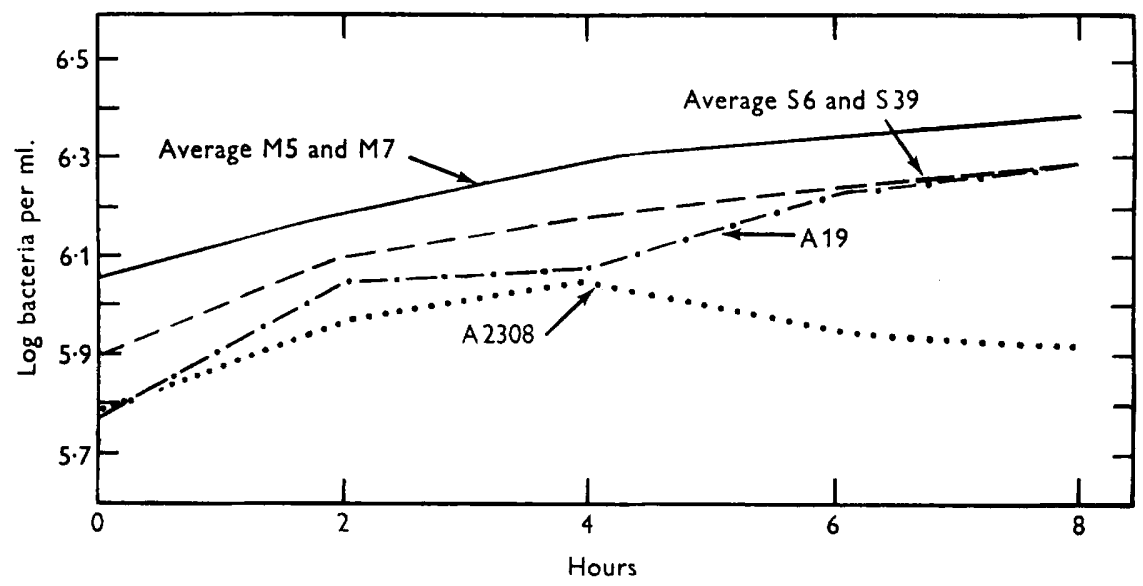

Fig. 1. The changes in bacterial count within $8 \mathrm{hr}$. in broth containing $1 \cdot 0 \mu \mathrm{g}$. streptomycin $/ \mathrm{ml}$.

Streptomycin. Streptomycin sulphate (Squibb) was used in all experiments.

Technique. All experiments were carried out in test-tubes of $20 \mathrm{~mm}$. diameter. The total volume of liquid medium containing the streptomycin and the bacterial inoculum was $10.0 \mathrm{ml}$. The wide test-tubes containing this relatively small quantity of fluid were thoroughly agitated and then incubated at $37^{\circ}$. Small samples of tube contents were taken at intervals, serial dilutions prepared $(1 / 40,1 / 1600,1 / 64,000,1 / 2,560,000)$ and $1.0 \mathrm{ml}$. of each dilution poured to agar plates. At those stages of the experiments where the bacterial count was low the samples were diluted less, and finally the undiluted contents of the tube were poured into agar plates. Fig. 1 represents the number of micro-organisms $/ \mathrm{ml}$. found at different intervals within $8 \mathrm{hr}$. in contact with $1.0 \mu \mathrm{g}$. streptomycin $/ \mathrm{ml}$. Of the six strains examined five tended to grow, while one strain (A 2308) after an initial rise showed a definite decrease in the number of organisms, beginning at the fourth hour.

Fig. 2 shows the behaviour of the bacteria from the tenth hour after contact with $1 \cdot 0 \mu \mathrm{g}$. streptomycin $/ \mathrm{ml}$. All strains show a gradual decrease of the 
number of bacteria; two (M7 and A 2308) were completely sterile after 24 hr.; the other four strains contained many living bacteria.

Fig. 3 shows the further behaviour of the four surviving strains. All of them showed on the following days in contact with streptomycin a steady increase of their bacterial count, strain M5 after a slight decrease continuing 2 days. This behaviour of the micro-organisms in the presence of streptomycin was modified under different conditions. With a greater inoculum the number of bacteria did not decrease below $10^{8} / \mathrm{ml}$. and a S-shape curve resulted. When the concentration of streptomycin was $100 \mu \mathrm{g} . / \mathrm{ml}$. the number of bacteria decreased after $4 \mathrm{hr}$. incubation.

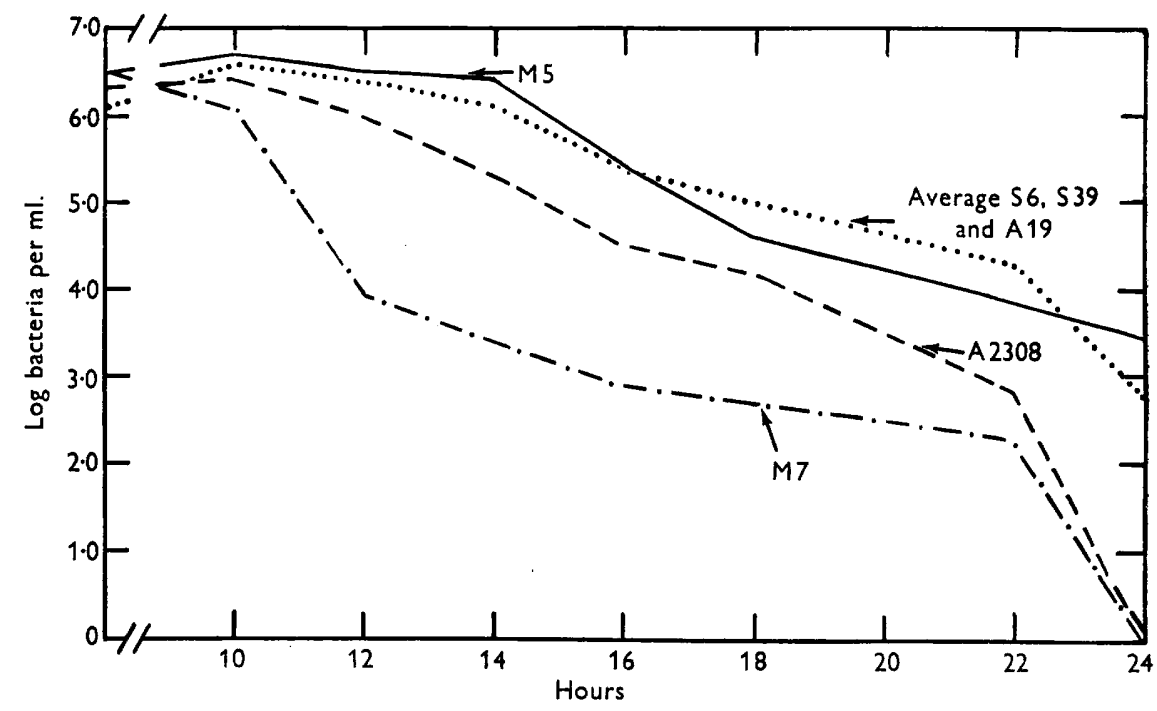

Fig. 2. The changes in bacterial count within $24 \mathrm{hr}$. in broth containing $1 \cdot 0 \mu \mathrm{g}$. streptomycin $/ \mathrm{ml}$.

These experiments showed that the rate of disappearance of the non-resistant bacteria and the time of the initial growth of the resistant bacteria depend upon the concentration of streptomycin and upon the number of organisms in the inoculum. It was necessary to decide whether the bacteria resistant to a given concentration of streptomycin were resistant only to this concentration or whether they had acquired complete resistance. In an experiment carried out with three different inocula of strain M5 exposed to $1 \cdot 0 \mu \mathrm{g}$. streptomycin/ $\mathrm{ml}$. for $\mathbf{2 4} \mathrm{hr}$. the following results were obtained:

$\begin{array}{llll}\text { Initial inocula } / 10 \mathrm{ml} . & 6.5 \times 10^{6} & 1.3 \times 10^{7} & 2.6 \times 10^{7} \\ \text { Surviving bacteria after } 24 \mathrm{hr} . / 10 \mathrm{ml} . & 5.8 \times 10^{3} & 1.5 \times 10^{5} & 6.9 \times 10^{5}\end{array}$

The figures show that the percentage of surviving bacteria increases with the increase of inoculum size. About 100 single colonies were picked and transferred to plain agar, and the resulting cultures transferred to agars 
containing $1 \cdot 0,10 \cdot 0$ and $100 \cdot 0 \mu \mathrm{g}$. streptomycin $/ \mathrm{ml}$. The results obtained with the surviving bacteria from the three inocula were very similar:

$\begin{array}{lllllll}\text { Inoculum } & \ldots & \ldots & 1 & \mathbf{2} & \mathbf{3}\end{array}$

Total colonies tested

Growing on $1 \cdot 0 \mu \mathrm{g} . / \mathrm{ml}$.

Growing on 10.0 and $100 \cdot 0 \mu \mathrm{g} . / \mathrm{ml}$.

$\begin{array}{rrr}1 & 2 & 3 \\ 31 & 33 & 32 \\ 30 & 30 & 28 \\ 1 & 1 & 1\end{array}$

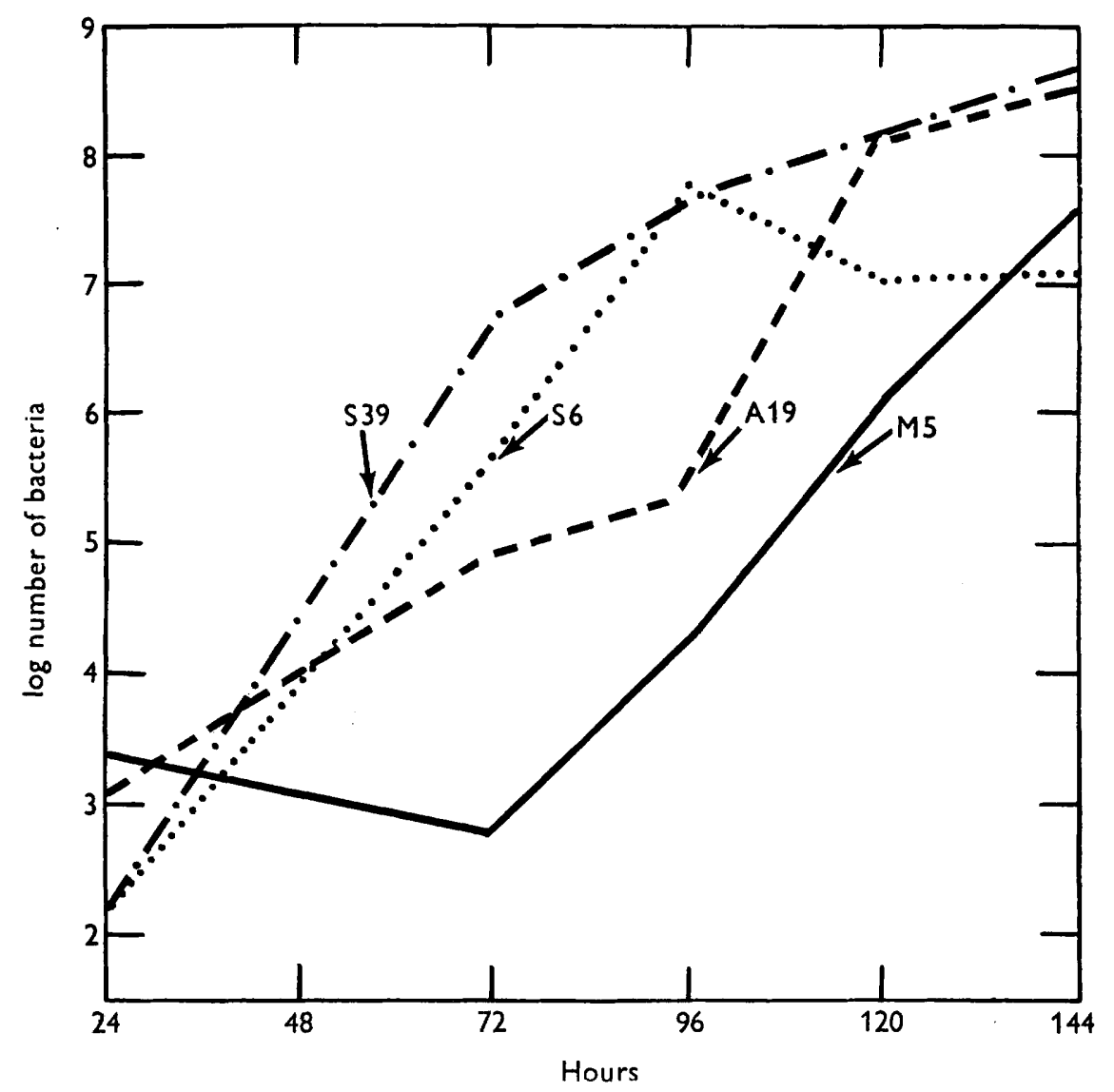

Fig. 3. The changes in bacterial count $24-144 \mathrm{hr}$. in broth containing $1 \cdot 0 \mu \mathrm{g}$. streptomycin $/ \mathrm{ml}$. Development of resistant micro-organisms.

This experiment showed that after $24 \mathrm{hr}$. the surviving bacteria were nearly all resistant to $\mathbf{1} \cdot 0 \mu \mathrm{g}$. streptomycin $/ \mathrm{ml}$., but only about $3 \%$ were resistant to higher concentrations. All bacteria resistant to $10 \mu \mathrm{g} . / \mathrm{ml}$. were resistant to $100 \cdot 0 \mu \mathrm{g} . / \mathrm{ml}$. Similar experiments were carried out with other strains exposed to different streptomycin concentrations. Most of the strains isolated at $1.0 \mu \mathrm{g}$. $/ \mathrm{ml}$. were resistant only against this concentration. Of 284 strains isolated at $1.0 \mu \mathrm{g} . / \mathrm{ml}$. 17 were resistant against 10 or more $\mu \mathrm{g} . / \mathrm{ml}$. When a strain tolerated the tenfold concentration then it also tolerated all higher concentrations up to $1000 \mu \mathrm{g}$. $/ \mathrm{ml}$. On the other hand, all the strains 
isolated from broth containing 10 and $100 \mu \mathrm{g}$. streptomycin $/ \mathrm{ml}$. tolerated all the higher concentrations up to $1000 \mu \mathrm{g} . / \mathrm{ml}$.

In these brucella cultures there appear to be present mainly two streptomycin-resistant variants : (1) variants partially resistant to $1 \mu \mathrm{g} . / \mathrm{ml}$. but not resistant to higher concentrations; (2) completely resistant variants resistant to 10 and $100 \mu \mathrm{g} . / \mathrm{ml}$. and higher concentrations. The following experiments were, therefore, carried out at $1 \cdot 0,10.0$ and $100 \cdot 0 \mu \mathrm{g} . / \mathrm{ml}$. to determine the MPN of the partially and completely resistant cells present in different cultures.

Determination of the $M P N$ of organisms resistant to $1 \cdot 0 \mu$ g. streptomycin $/ \mathrm{ml}$.

To determine the MPN, 24 hr. broth cultures were diluted in tenfold steps and from suitable dilutions $1 \mathrm{ml}$. volumes were added to tubes containing $9 \mathrm{ml}$. broth, and streptomycin added in the required concentration. After preliminary experiments to determine after a 5-day incubation period the range of inocula just sufficient to give resistant organisms, three inocula around this critical limit were selected and five broth tubes seeded with each inoculum. The inocula sizes differed by a factor of 10. The MPN was determined after incubation for 5 days for an inoculum ten times greater than the largest inoculum used in the experiment, by means of the tables of Hoskins (1934).

Table 1. Determination of the most probable number $(M P N)$ of brucella cells resistant to $1 \cdot 0 \mu g$. streptomycin $/ \mathrm{ml}$. in $\mathbf{2 4} \mathrm{hr}$. broth cultures

\begin{tabular}{|c|c|c|c|c|c|c|c|c|}
\hline \multirow[b]{2}{*}{ Strain } & \multicolumn{3}{|c|}{ Size of inocula } & \multicolumn{3}{|c|}{$\begin{array}{l}\text { Positive results } \\
\text { per } 5 \text { portions } \\
\text { of each inoculum }\end{array}$} & \multirow[b]{2}{*}{ MPN } & \multirow{2}{*}{$\begin{array}{c}\text { No. of } \\
\text { organisms } \\
\text { per resistant } \\
\text { cell }\end{array}$} \\
\hline & 1 & $\mathbf{2}$ & 3 & 1 & 2 & $\mathbf{3}$ & & \\
\hline M5 & $1.8 \times 10^{7}$ & $1.8 \times 10^{6}$ & $1.8 \times 10^{5}$ & 5 & 0 & 0 & $23 / 1.8 \times 10^{8}$ & $7 \cdot 8 \times 10^{6}$ \\
\hline M7 & $3.5 \times 10^{7}$ & $3.5 \times 10^{6}$ & $3.5 \times 10^{5}$ & $\mathbf{1}$ & $\mathbf{0}$ & $\mathbf{0}$ & $2 / 3.5 \times 10^{8}$ & $1.8 \times 10^{8}$ \\
\hline S39 & $1.2 \times 10^{7}$ & $1.2 \times 10^{6}$ & $1.2 \times 10^{5}$ & 4 & 0 & $\mathbf{0}$ & $13 / 1.2 \times 10^{8}$ & $9.2 \times 10^{6}$ \\
\hline S6 & $2.6 \times 10^{7}$ & $2.6 \times 10^{6}$ & $2.6 \times 10^{5}$ & $\mathbf{5}$ & $\mathbf{0}$ & o & $23 / 2.6 \times 10^{8}$ & $1.1 \times 10^{7}$ \\
\hline A 19 & $1.3 \times 10^{7}$ & $1.3 \times 10^{6}$ & $1.3 \times 10^{5}$ & 5 & 0 & 0 & $23 / 1.3 \times 10^{8}$ & $5.7 \times 10^{6}$ \\
\hline A2308 & $3.2 \times 10^{7}$ & $3.2 \times 10^{6}$ & $3.2 \times 10^{5}$ & $\mathbf{1}$ & $\mathbf{0}$ & $\mathbf{0}$ & $2 / 3.2 \times 10^{8}$ & $1.6 \times 10^{8}$ \\
\hline
\end{tabular}

Table 1 shows the results of a typical experiment. There exist marked differences between the other strains and strains M7 and A2308 which, in the experiment shown in Fig. 3, did not produce resistant organisms since the inoculum was too small. The results in Table 1 explain this previous result. The strains $\mathrm{M} 7$ and $\mathbf{A} 2308$ had only one resistant cell among at least $10^{8}$; all the other strains had resistant cells in much smaller bacterial populations. The experiment shows that it is possible to determine the MPN of organisms resistant to a certain concentration of streptomycin when the following conditions are fulfilled: (1) the largest inoculum must be great enough to enable the appearance of resistant variants in at least one of five tubes; (2) the smallest inoculum must be small enough to enable resistant variants to appear in less than five tubes. When resistant organisms appear in all five 
tubes inoculated with the smallest inoculum their number cannot of course be calculated.

Table 2. Variation with time of the number of cells resistant to $1.0 \mu \mathrm{g}$. streptomycin/ml. in cultures originating from a single colony

\begin{tabular}{|c|c|c|c|}
\hline Strain & $\begin{array}{l}\text { Age of } \\
\text { culture } \\
\text { (days) }\end{array}$ & MPN & $\begin{array}{l}\text { No. of } \\
\text { organisms per } \\
\text { resistant cell }\end{array}$ \\
\hline M5 & $\begin{array}{r}1 \\
\mathbf{3} \\
17\end{array}$ & $\begin{array}{r}23 / 1.8 \times 10^{8} \\
240 / 2.0 \times 10^{9} \\
79 / 1.4 \times 10^{8}\end{array}$ & $\begin{array}{l}7 \cdot 8 \times 10^{6} \\
8.3 \times 10^{6} \\
1.8 \times 10^{6}\end{array}$ \\
\hline $\mathrm{M} 7$ & $\begin{array}{r}1 \\
3 \\
17 \\
25 \\
30\end{array}$ & $\begin{array}{r}2 / 3.5 \times 10^{8} \\
2 / 1.7 \times 10^{8} \\
27 / 4.0 \times 10^{8} \\
22 / 2.0 \times 10^{8} \\
13 / 4.0 \times 10^{8}\end{array}$ & $\begin{array}{l}1.8 \times 10^{8} \\
8 \cdot 5 \times 10^{7} \\
1.5 \times 10^{7} \\
9 \cdot 1 \times 10^{6} \\
3 \cdot 1 \times 10^{7}\end{array}$ \\
\hline S39 & $\begin{array}{r}1 \\
3 \\
17\end{array}$ & $\begin{array}{r}13 / 1.2 \times 10^{8} \\
2 / 2.1 \times 10^{7} \\
240 / 8.0 \times 10^{6}\end{array}$ & $\begin{array}{l}9 \cdot 2 \times 10^{6} \\
1 \cdot 1 \times 10^{7} \\
3 \cdot 3 \times 10^{4}\end{array}$ \\
\hline S 6 & $\begin{array}{r}\mathbf{1} \\
\mathbf{3} \\
\mathbf{2 5} \\
\mathbf{3 0}\end{array}$ & $\begin{array}{r}23 / 2 \cdot 6 \times 10^{8} \\
9 / 2 \cdot 2 \times 10^{7} \\
13 / 2 \cdot 0 \times 10^{7} \\
13 / 8.2 \times 10^{7}\end{array}$ & $\begin{array}{l}1.1 \times 10^{7} \\
2.4 \times 10^{6} \\
1.6 \times 10^{6} \\
6.6 \times 10^{6}\end{array}$ \\
\hline A19 & $\begin{array}{r}1 \\
3 \\
17\end{array}$ & $\begin{array}{r}23 / 1.3 \times 10^{8} \\
2 / 3 \cdot 0 \times 10^{6} \\
1600 / 6.0 \times 10^{6}\end{array}$ & $\begin{array}{l}5.7 \times 10^{6} \\
1.5 \times 10^{6} \\
3.8 \times 10^{3}\end{array}$ \\
\hline A2308 & $\begin{array}{r}1 \\
3 \\
25\end{array}$ & $\begin{array}{r}2 / 3.2 \times 10^{8} \\
2 / 1.6 \times 10^{8} \\
180 / 1.6 \times 10^{8}\end{array}$ & $\begin{array}{l}1.6 \times 10^{8} \\
8.0 \times 10^{7} \\
9.0 \times 10^{5}\end{array}$ \\
\hline
\end{tabular}

Table 2 shows that the MPN varies with age of culture. The general trend seems to be that in older more dissociated cultures the MPN of resistant variants increases. This increase of resistant cells was very marked in the cultures of the strains S 39, A19 and A2308.

Determination of the MPN of resistant cells at 10 and $100 \mu \mathrm{g}$. streptomycin/ml.

Using different inoculum sizes at a constant concentration of streptomycin it was not possible to determine the minimal inoculum necessary to give resistant strains in streptomycin concentrations of 10 and $100 \mu \mathrm{g} . / \mathrm{ml}$. since resistant organisms appeared in many instances in smaller inocula, while relatively large inocula did not give resistant strains. A typical experiment is recorded in Table 3 which shows that, using only one tube for each inoculum, it is impossible to find a clear limit between inocula large enough and those too small to give rise to resistant variants. There exists, therefore, only the possibility of determining the MPN of resistant organisms in the total bacterial population. Since all the strains isolated at $10 \mu \mathrm{g} . / \mathrm{ml}$. were also resistant to all the higher concentrations all the following experiments were carried out at $100 \mu \mathrm{g} . / \mathrm{ml}$. To determine this number the method for the calculation of small numbers of coliform bacteria was used; 10.0, 1.0 and $0.1 \mathrm{ml}$. of $24 \mathrm{hr}$. broth cultures were inoculated into broth tubes containing 
Table 3. The appearance of resistant forms in cultures exposed to 10 and $100 \mu$ g. streptomycin $/ \mathrm{ml}$. for 10 days at $37^{\circ}$

Streptomycin
$(\mu \mathrm{g} . / \mathrm{ml}$.
$10 \cdot 0$

$100 \cdot 0$

\begin{tabular}{|c|c|c|c|c|c|c|c|}
\hline \multirow[b]{2}{*}{ Strain } & \multicolumn{7}{|c|}{ No. of organisms inoculated $/ 10 \mathrm{ml} .\left(\times 10^{6}\right)$} \\
\hline & 64 & 160 & 320 & 640 & 1600 & 3200 & 8000 \\
\hline M5 & $\mathbf{0}$ & 0 & 0 & 0 & $\mathbf{R}$ & - & - \\
\hline M7 & 0 & 0 & 0 & 0 & $\mathbf{R}$ & . & . \\
\hline S39 & 0 & 0 & o & $\mathbf{R}$ & 0 & . & . \\
\hline S6 & $\mathbf{0}$ & 0 & $\mathbf{R}$ & 0 & $\mathbf{0}$ & . & . \\
\hline A 19 & $\mathbf{0}$ & 0 & 0 & $\mathbf{R}$ & $\mathbf{0}$ & . & • \\
\hline A 2308 & 0 & $\mathbf{0}$ & o & 0 & o & . & $\cdot$ \\
\hline M5 & • & . & 0 & 0 & $\mathbf{R}$ & o & 0 \\
\hline M7 & . & . & 0 & 0 & 0 & $\mathbf{0}$ & $\mathbf{R}$ \\
\hline S89 & . & . & $\mathbf{R}$ & $\mathbf{0}$ & 0 & 0 & 0 \\
\hline S6 & . & . & 0 & 0 & $\mathbf{R}$ & 0 & 0 \\
\hline A 19 & . & . & $\mathbf{R}$ & 0 & $\mathbf{R}$ & $\mathbf{0}$ & 0 \\
\hline A 2308 & . & . & $\mathbf{R}$ & 0 & $\mathbf{R}$ & $\mathbf{0}$ & 0 \\
\hline
\end{tabular}

$0=$ no appearance of resistant organisms.

$\mathbf{R}=$ resistant organisms appeared.

$100 \mu \mathrm{g}$. streptomycin $/ \mathrm{ml}$. For the inoculation of $10 \cdot 0 \mathrm{ml}$. of culture, tubes containing $10 \cdot 0 \mathrm{ml}$. broth $+200 \mu \mathrm{g}$. streptomycin $/ \mathrm{ml}$. were used in order to bring the final concentration to $100 \mu \mathrm{g}$. $/ \mathrm{ml}$. Five tubes were used for each size of inoculum. The results are summarized in Table 4 which shows that not all

Table 4. The MPN of brucella cells resistant to $100 \mu \mathrm{g}$. streptomycin $/ \mathrm{ml}$. determined for $100 \mathrm{ml}$. of $24 \mathrm{hr}$. broth cultures

Five replicate tubes were inoculated with varying amounts, to give three tenfold dilutions.

\begin{tabular}{|c|c|c|c|c|c|c|}
\hline \multirow[b]{3}{*}{$\begin{array}{c}\text { Strain } \\
\text { examined }\end{array}$} & \multicolumn{3}{|c|}{ Volume (ml.) } & \multirow[b]{3}{*}{$\begin{array}{c}\text { MPN } \\
\text { (resistant } \\
\text { cells/100 ml.) }\end{array}$} & \multirow[b]{3}{*}{$\begin{array}{l}\text { Total no. of } \\
\text { organisms/ } \\
100 \mathrm{ml} .\end{array}$} & \multirow[b]{3}{*}{$\begin{array}{c}\text { No. of } \\
\text { organisms/ } \\
\text { resistant cell }\end{array}$} \\
\hline & $10 \cdot 0$ & 1.0 & $0 \cdot 1$ & & & \\
\hline & \multicolumn{3}{|c|}{$\begin{array}{l}\text { No. of positives } \\
\text { in } 5 \text { portions }\end{array}$} & & & \\
\hline M5 & 1 & 0 & 0 & $\mathbf{2 \cdot 0}$ & $3.5 \times 10^{10}$ & $1.8 \times 10^{10}$ \\
\hline M7 & $\mathbf{1}$ & 1 & 0 & $4 \cdot 0$ & $4.5 \times 10^{10}$ & $1.1 \times 10^{10}$ \\
\hline S39 & 4 & 1 & $\mathbf{1}$ & $21 \cdot 0$ & $4.3 \times 10^{10}$ & $2.0 \times 10^{\theta}$ \\
\hline S6 & 3 & 1 & 0 & 11.0 & $4.5 \times 10^{10}$ & $4.1 \times 10^{9}$ \\
\hline A 19 & $\mathbf{0}$ & 2 & 0 & $3 \cdot 7$ & $2 \cdot 6 \times 10^{10}$ & $7 \cdot 0 \times 10^{9}$ \\
\hline A 2308 & 4 & $\mathbf{3}$ & 0 & $27 \cdot 0$ & $3.1 \times 10^{10}$ & $1.1 \times 10^{9}$ \\
\hline
\end{tabular}

strains were equally able to produce completely resistant variants. Considerable quantitative differences existed and under the conditions of the experiment strain M5 was only once able to produce a resistant variant with an inoculum of $10.0 \mathrm{ml}$. Strain A19 also showed irregular behaviour; it produced resistant variants with an inoculum of $1.0 \mathrm{ml}$. in two tubes, but did not produce resistant variants in any of the $5 \mathrm{vol}$. of $10.0 \mathrm{ml}$. The ability of the strains M5 and A19 to produce resistant variants was therefore re-examined using larger volumes of broth cultures. Five volumes of $100 \mathrm{ml} ., 5 \mathrm{of} 10 \mathrm{ml}$. and 5 of $1 \mathrm{ml}$. were used; concentration streptomycin $100 \mu \mathrm{g} . / \mathrm{ml}$. To the 100 and 
$10 \mathrm{ml}$. volumes equal volumes of broth $+200 \mu \mathrm{g}$. streptomycin $/ \mathrm{ml}$. were added to bring the final concentration to $100 \mu \mathrm{g} . / \mathrm{ml}$. This experiment is summarized in Table 5. It is interesting to note that the figure obtained in this experiment for the strain M5 was the same as obtained previously (cf. Table 4). The figure for A 19 was about twice that obtained in the previous experiment. The MPN of cells resistant to $100 \mu \mathrm{g} . / \mathrm{ml}$. remained fairly constant at the different periods of incubation, although in this case also the general trend seemed to show an increase of resistant cells with the age of culture (Table 6).

Table 5. The most probable numbers of brucella cells resistant to $100 \mu g$. streptomycin/ml. determined for $1000 \mathrm{ml}$. of broth cultures of strains M5 and A19

Five portions of each volume, 100, 10 and $1 \mathrm{ml}$., were seeded.

\begin{tabular}{|c|c|c|c|c|c|c|}
\hline \multirow[b]{3}{*}{ Strain } & \multicolumn{3}{|c|}{ Volume (ml.) } & \multirow{3}{*}{$\begin{array}{c}\text { MPN } \\
\text { resistant } \\
\text { organisms/ } \\
1000 \mathrm{ml} .\end{array}$} & \multirow[b]{3}{*}{$\begin{array}{l}\text { Total no. of } \\
\text { organisms/ } \\
1000 \mathrm{ml} .\end{array}$} & \multirow{4}{*}{$\begin{array}{c}\text { No. of } \\
\text { organisms/ } \\
\text { resistant cell }\end{array}$} \\
\hline & $100 \cdot 0$ & $10 \cdot 0$ & $1 \cdot 0$ & & & \\
\hline & \multicolumn{3}{|c|}{$\begin{array}{l}\text { No. of positives } \\
\text { in } 5 \text { portions }\end{array}$} & & & \\
\hline M5 & 4 & 1 & 1 & $21 \cdot 0$ & $3.8 \times 10^{11}$ & \\
\hline A 19 & 3 & 1 & 0 & $11 \cdot 0$ & $2.6 \times 10^{11}$ & $2 \cdot 4 \times 10^{10}$ \\
\hline
\end{tabular}

Table 6. Variation in the number of cells resistant to $100 \mu \mathrm{g}$. streptomycin/ml. in cultures originating from a single colony

$\begin{array}{cccc}\text { Age of } & \begin{array}{c}\text { culture } \\ \text { (days) }\end{array} & \text { MPN } & \begin{array}{c}\text { No. of } \\ \text { organisms/ } \\ \text { resistant cell }\end{array} \\ \text { M7 } & 3 & 4 \cdot 0 / 6 \times 10^{10} & 1.5 \times 10^{10} \\ \text { A19 } & 30 & 10 \cdot 0 / 4 \times 10^{8} & 4.0 \times 10^{7} \\ & 3 & 4.0 / 3 \times 10^{10} & 7 \cdot 5 \times 10^{9} \\ \text { A2308 } & 17 & 23.0 / 12 \times 10^{9} & 5 \cdot 2 \times 10^{8} \\ & 3 & 1 \cdot 8 / 25 \times 10^{9} & 1.4 \times 10^{10} \\ & 17 & 27 \cdot 0 / 31 \times 10^{8} & 1.1 \times 10^{8} \\ & 30 & 4.5 / 8 \times 10^{7} & 1.8 \times 10^{7}\end{array}$

Agreement between the determination of the MPN with other methods

The figures obtained by the MPN method were compared with the results of direct observation of resistant cells when large quantities of culture were plated out in the presence of $100 \mu \mathrm{g}$. streptomycin $/ \mathrm{ml}$. The method was compared with the centrifugation method in which the whole bacterial growth from $100 \mathrm{ml}$. of culture was collected on a refrigerated centrifuge and poured in plates containing $100 \mu \mathrm{g}$. streptomycin $/ \mathrm{ml}$, and with a simple plating method in which only $2.0 \mathrm{ml}$. of culture were removed and plated with the same concentration of streptomycin. A comparison was made between the growth of a strain known to be resistant to $100 \mu \mathrm{g}$. streptomycin $/ \mathrm{ml}$., starting from an inoculum of about 5 cells $/ 100 \mathrm{ml}$, and the growth of the resistant cells surviving from a $48 \mathrm{hr}$. non-resistant culture to which $50 \%(\mathrm{v} / \mathrm{v})$ of fresh broth and $100 \mu \mathrm{g}$. streptomycin $/ \mathrm{ml}$. were added. 
Table 7 shows that the results of the MPN method agree with those obtained by the centrifugation method until the upper limit of 1600 cells $/ 100 \mathrm{ml}$. of broth culture is reached. The direct plating method does not give reliable results so long as the number of resistant cells is lower than 100/100 ml. With

Table 7. Streptomycin resistant cells appearing in a culture of a non-resistant strain exposed to $100 \mu \mathrm{g}$. streptomycin $/ \mathrm{ml}$., and from the culture of a resistant strain exposed to the same concentration of streptomycin

\begin{tabular}{|c|c|c|c|c|c|c|c|}
\hline \multirow[b]{3}{*}{ Strain } & \multirow{3}{*}{$\begin{array}{c}\text { Time } \\
\text { (hr.) }\end{array}$} & \multicolumn{2}{|c|}{$\begin{array}{l}\text { No. of resistant bacteria deter- } \\
\text { mined by pouring plates with } \\
100 \mu \mathrm{g} \text {. streptomycin } / \mathrm{ml} \text {. and }\end{array}$} & \multirow{2}{*}{\multicolumn{4}{|c|}{$\begin{array}{l}\text { Determination of } \\
\text { MPN } / 100 \mathrm{ml} . \\
\text { broth culture }\end{array}$}} \\
\hline & & \multirow{2}{*}{$\begin{array}{l}2 \text { ml. } \\
\text { culture }\end{array}$} & \multirow{2}{*}{$\begin{array}{l}\text { the sediment } \\
\text { of } 100 \mathrm{ml} . \\
\text { culture }\end{array}$} & & & & \\
\hline & & & & $10 \cdot 0$ & $1 \cdot 0$ & $0 \cdot 1$ & MPN \\
\hline S38 & $\mathbf{0}$ & $\mathbf{0}$ & 16 & 4 & 2 & 0 & 22 \\
\hline \multirow{6}{*}{ non-resistant } & 10 & 0 & 23 & 5 & 1 & 0 & 33 \\
\hline & 14 & 0 & 26 & $\mathbf{5}$ & 2 & 0 & 49 \\
\hline & 18 & 2 & 59 & 5 & $\mathbf{1}$ & $\mathbf{0}$ & 33 \\
\hline & 22 & 2 & 78 & 5 & 4 & 0 & 130 \\
\hline & 34 & 22 & 340 & 5 & 5 & 3 & 920 \\
\hline & 58 & 890 & 12,000 & . & . & - & - \\
\hline S39 & o & 0 & 5 & 3 & 0 & $\mathbf{0}$ & $7 \cdot 8$ \\
\hline \multirow[t]{5}{*}{ resistant } & 10 & 4 & 124 & 5 & 4 & 0 & 130 \\
\hline & 14 & 14 & 278 & 5 & 5 & 3 & 920 \\
\hline & 18 & 80 & $1, \mathbf{5 5 0}$ & $\mathbf{5}$ & 5 & 4 & 1,600 \\
\hline & 22 & 265 & 5,560 & 5 & 5 & 5 & . \\
\hline & $\mathbf{3 4}$ & $46,000^{*}$ & $960,000^{*}$ & 5 & 5 & 5 & . \\
\hline
\end{tabular}

an increase of number of resistant organisms above 1000 the direct plating methods without or with suitable dilutions is the method of choice. The experiment presented in Table 7 also shows that in the non-resistant S39 strain, resistant bacteria were present in the culture at the time when streptomycin was added and that these bacteria multiplied slowly after a prolonged lag phase which lasted about $14 \mathrm{hr}$.

\section{REFERENCES}

ENGLish, A. R. \& McCox, E. (1951). A study of streptomycin resistance in Micrococcus pyogenes var. aureus. J. Bact. 61, 51.

Hoskins, J. K. (1934). The most probable number for the evaluation of coliaerogenes tests by fermentation tube method. Publ. Hlth Rep., Wash. 49393.

KLein, M. \& Kimmelman, L. J. (1946). The role of spontaneous variants in the acquisition of streptomycin resistance by the Shigellae. J. Bact. 52, 471.

McCrady, M. H. (1915). The numerical interpretation of fermentation tube results. J. infect. Dis. 17, 183.

Standard Methods for the Examination of Water and Sewage, 8th ed., pp. 220-1 (1936). New York: Amer. Publ. Hith Ass.

Yegian, D. \& VANDERLinde, R. J. (1948). A quantitative analysis of the resistance of Mycobacteria to streptomycin. J. Bact. 56, 177.

(Received 13 August 1951) 